\title{
Covid-19, Business Failure and Bank Loan Collapse: Albanian Case
}

\author{
Romeo Mano ${ }^{1, *}$, Armela Anamali ${ }^{1}$, Bitila Shosha ${ }^{2}$ \\ ${ }^{1}$ Department of Mathematics, Informatics and Physics, Faculty of Natural Sciences, University “Eqrem Çabej” Gjirokastër, Albania \\ ${ }^{2}$ Department of Finance and Accounting, Faculty of Business, University “Aleksander Moisu”, Durrës, Albania
}

Received June 20, 2021; Revised July 23, 2021; Accepted September 8, 2021

\begin{abstract}
Cite This Paper in the following Citation Styles
(a): [1] Romeo Mano, Armela Anamali, Bitila Shosha, "Covid-19, Business Failure and Bank Loan Collapse: Albanian Case," Universal Journal of Accounting and Finance, Vol. 9, No. 5, pp. 1058 - 1066, 2021. DOI: 10.13189/ujaf.2021.090516.
\end{abstract}

(b): Romeo Mano, Armela Anamali, Bitila Shosha (2021). Covid-19, Business Failure and Bank Loan Collapse: Albanian Case. Universal Journal of Accounting and Finance, 9(5), 1058 - 1066. DOI: 10.13189/ujaf.2021.090516.

Copyright $\bigcirc 2021$ by authors, all rights reserved. Authors agree that this article remains permanently open access under the terms of the Creative Commons Attribution License 4.0 International License

\begin{abstract}
Purpose. The purpose of this paper is to make an analysis of challenges to private sectors repaying bank loans during and after lockdown restrictions imposed by Albanian government due to Covid-2019 pandemic, and their prospects for bank lending. Design/ Methodology/ Approach. This paper uses a mixed methodology. To collect primary data, we distributed online questionnaires to a number of Albanian firms. The sample collected is a probability sample of business population operating in Albania. The data collected are subsequently processed with the inferential statistical methods using SPSS version 21. Findings. This study identifies and examines the impact of Covid-19 on businesses that have taken credits during the pre-pandemic period. The results indicate that the risk of deferring loan repayments depends on businesses age, i.e., years of operating in the market, and the use of cash reserve funds of business. The need for liquidity and the perspective shows that firms are reluctant and not sure whether to opt for a bank loan. The factors influencing their decision in this regard are government policies, interest rates and uncertainty in the future. Originality/value. By analyzing the relationship between two important pillars of the domestic economy, this paper represents a novelty. Albania is a developing country and this study would help in future research both for Albania and other similar countries. The findings of this paper can also be used as a baseline for a future forecast model. They could help in analyzing private sector credits in a new socio-economic and geopolitical era caused by Covid-19 pandemic.
\end{abstract}

Keywords Covid-19 Pandemic, Private Sector, Bank Loan, Interest Rates, Government Policies

JEL: D22, D60, D81, G21, G33

\section{Introduction}

The Albanian banking system is the main source of the growth and performance of Albanian firms. Domestic and foreign economic and political factors, as well as internal business factors have often disrupted the financial balances. Several researches have after the global financial crisis effects of 2008, focused on variables influencing credit risk, such as: business environment, nature of industry, level of corruption, banking policies and restrictions, interest rates, size or nature of business, high debt ratio, business performance, etc. However, no study has predicted what kind of effects a global pandemic could have on a country or the global economy. Earlier research has shown the effects of decision-making and actions of society on a country's economy, but not a pandemic effects and reflections on further society behavior. This new approach is applicable in all areas of life. However, in many countries like Albania, where the balances are more fragile, Covid-19 pandemic was a shock for many sectors of the country, such as health, education, tourism, transport, etc.

Only in a few weeks, the outbreak of Covid-19 changed the world. As the health and geopolitical crisis of the 21st 
century, the pandemic spilled over very rapidly into both financial markets and the real economy worldwide [1]. Albania reported the first Covid-19 case in early March 2020 and the number gradually increased. To avoid the health crisis that the neighboring country, Italy, was facing, the Albanian Government immediately introduced measures to prevent virus spread and imposed a total lockdown of the country on 24 March 2020. Total shutdown of the country created huge difficulties for the private sector. Despite the measures adopted by the government and the Bank of Albania, many businesses faced the liquidity challenges and were unable to cover their expenses and liabilities. The most common challenges they faced were the drop in sales, shortage of liquidity, difficulties to pay wages and taxes [2]. One sector that directly and indirectly experienced the pandemic crisis was the financial sector, as it had major difficulties in loan repayment from businesses and cash flow.

Understanding the challenges of Albanian businesses experienced during the last year would be helpful in identifying the "financial health" of private sector, the capacity of businesses to meet the sunk costs (i.e., investments and expenses that could not be recovered) and to achieve the strategies pursued to settle an unavoidable debt, such as bank loans. Banks and businesses are two important pillars of domestic economy, without which it is impossible to have welfare and economic growth. If one of the pillars is shaking, this would inevitably bring challenges to the other. So, the onset of this pandemic gave a hint of what is going to happen with these sectors in the presence of a worldwide pandemic such as Covid-19. Despite being one of the first researches of this kind for Albania, this paper intends to analyze the difficulties that private sector faced while trying to comply with various contracts with banking institutions and the prospects of their future.

\section{Literature Review}

After conducting a literature review, we found out that an increasing number of research and papers focused on and examined the impacts of Covid-19 pandemic. The nature of articles is diverse. The first data were analyzed at local, regional, and global level [3-8]. A pandemic can last from 10-50 years the emergence of new variants of the virus [9], so nothing can be predicted. Learning from previous practice and research increases the possibility to avoid making mistakes that can have long-term consequences in a country.

In contrast to the 2008 financial crisis, Covid-19 pandemic is considered a global crisis [10,11]. All supply chains were broken for a long time, while some continue to remain partially or fully inactive. In the new era where production is geographically fragmented, malfunctioning supply chains imply broken links and disrupted trade flows [12]. During the COVID-19 outbreak, countries around the world faced a combined effect of supply and demand shock [13]. This pandemic impacted not only the lives, but also the economic welfare and social health of many countries, from developing to least developed countries [14].

With business revenue plummeting, company cash flows have collapsed at an unprecedented scale [13].By its nature, COVID-19 shock represents a loss of cash flow of indeterminate duration for firms [15],to the financial sector and, in particular, banks were expected to play an important role in absorbing the shock caused by Covid-19 [10]. However, we must remember that the financial sector operates in accordance with the economic and institutional framework of a country. For developing countries, their role is limited due to the weak institutional environment and high level of information ambiguity that exists for businesses in these countries [16] and even more if they are small businesses [17].

The firm's behavior during the pandemic has received less attention than consumer response [18].[19] state that Covid-19 pandemic has simultaneously increased both firm-level uncertainty and worsened business outlook in the majority of firms.

\section{Methodology of Study}

The literature review covered a considerable number of scholars, who have researched and published scientific papers in a short time during Covid-2019 global pandemic. During this phase, we were able to collect important and comparable data on the issues addressed in our paper as well. The literature review is of paramount value, not only for its reference value, but also for its sound basis of support in addressing the issues of our study, because Covid-2019 pandemic was a new unprecedented phenomenon.

This study covers companies located in two citiesDurrës and Tirana- where the distribution of firms is proportionate to the population demographics. We made sure to choose a representative sample by including 180 businesses from all major sectors, mainly those sectors immediately hit by Covid-2019, such as manufacturing, services, retail, etc. We distributed online questionnaires to collect primary data. Thereafter, the data were processed with the inferential statistical methods using SPSS version 21.

Being the key tool used to interview respondents, the questionnaires observed full confidentiality of respondents' identity. The purpose of the questionnaire was to collect primary data for our study, which could be useful in identifying the major difficulties businesses are facing due to the situation created by Covid-19 pandemic and their relationship with banks to mitigate their financial 
problems or difficulties. The validity and reliability of data is crucial in this regard. The data collected through the questionnaires were processed with the statistical software SPSS version 21.

After collection, we processed such data to ensure accurate, analytical, and comparable outcomes at national and international level. Such data could also serve as a baseline for further research. To better understand the problems and questions raised in this paper, and to reach the goal of our research, we constructed an econometric model based on correlations and variables. It contains a host of factors and respondent feedback to these factors.

The factors used, in this paper, as independent variables are: Business Size, Business Age, Covid-19 Impact, Activity during quarantine, Failure Perception, Accuracy of Receipts, Usage of cash reserves, Contract Terms, Interest Rate, Business Difficulties, Business Environment.

The first two variables are nominal variables, but in this study, they are used as ordinal representing respectively. The first is the size of the business $(1=$ small, $2=$ medium, $3=$ large $)$ and the second is its age $(1=$ Before $2000,2=$ During $2000-2009,3=$ During $2010-2015,4=$ After 2015).

The other variables are ordinal which are measured using the level of perception by increasing the Likert scale from $1=$ not at all to $5=$ fully.

Dependent variables are the variables with ordinal values: Credit as potential funding $(1=$ not at all $5=$ fully $)$ and Delay of Loan Repayment $(1=0$ months delay, $2=1$ month delay, $3=2$ months delay, $4=$ repayment delay by 3 months, 5 = repayment delay over 3 months)

After an empirical analysis of results, we were able to draw some conclusions. The analysis revealed that the firms' perception, shaped by Covid-2019 impacts, is to bring to a minimum their need for liquidity to avoid business failure.

\section{Empirical Analysis of Outcomes and Findings}

The sudden "environmental shock" triggered by COVID-19 has exponentially depleting firms' financial resources, and increased insolvency, creating financial distress in organizations and weakening the financial position of many large and small firms [20]. All businesses feared failure. However, based on our literature review, there seems to be no consensus as to the issues of liquidity, business failure and crediting experience of businesses "infected" from the pandemic.

Business failure refers to a situation where the business is no longer able to operate as a sustainable entity and is then forced to cease operations and lay off employees [21] An increase in business failures can also pose a risk to the banking sector through a rise in non-performing credits
[3]. Because financial systems play a key mediating role in channeling savings into productive activities, failure in this function can significantly exacerbate the already significant economic impact of the pandemic shock [22].

Impact of Covid-19 pandemic on firms that have taken a loan before the pandemic outbreak

Referring to the results of correlation between independent variables given in Table 1, we noted that firm's size is significantly related to failure perception due to Covid-19 impact on the firm and the perception of failure risk level.

Based on these correlations, we can conclude that big firms have a lower sensitivity in terms of pandemic impacts on their business, as well as a lower fear of business failure due to pandemic shock. A similar conclusion can be found in [23] and [24], which state that big firms are less exposed to pandemic risk than other forms of business. Meanwhile, small firms, more apparently, feel the impacts of pandemic on weakening their firm, as well as an increased fear of business failure risk. The reasons behind their perception that the pandemic and operational restrictions jeopardize their future are related to the nature of industry they operate and the drop of sales in these industries. Small businesses operate in industries such as accommodation, food services and retail. Physical distance and mandatory operational constraints changed consumer behavior $[25$, 18]. In addition, consumers are still reluctant to go in person in the premises of small businesses, because of the fear of getting infected and spreading the virus.

Compared to old businesses operating in the market, new businesses are more exposed to failure risk ( $\mathrm{PCC}=0.372$ ). New businesses are reported to be forced to use their business savings to cover the survival costs of their business $(\mathrm{PCC}=0.224)$. Increased perception of Covid-19 impact on business has significantly increased the level of perception of the risk of business failure ( $\mathrm{PCC}=0.392)$, because Covid-19 pandemic impacts on business was associated with the shutting down of business activities during the lockdown period ( $\mathrm{PCC}=-0.419)$.

Staying closed during the lockdown period meant for Albanian businesses, characterized by face-to-face interaction and a low degree of work-from-home [26], translated into a shortage of liquidity. This conclusion reinforces the negative correlation between the operating activity and the failure risk $(\mathrm{PCC}=-0.338)$, i.e., a working business activity is accompanied with a decline in failure risk according to the business perception shown in the study. Small-size entrepreneurs, who depend on regular sales and have small financial reserves and limited access to external financing sources, are those who fear most financial risk, as it may mean the dissolution of their business [27].

At last, the level of failure risk is significantly 
correlated with the use of business cash reserves to cover expenses $(\mathrm{PCC}=0.360)$. This indicates that one of the reasons for fear of business failure and logically guided firms towards bank lending is the decrease of cash reserves due to the pandemic. Lockdown measure taken in response to COVID-19 pandemic triggered a high liquidity demand for firms affected by the crisis [28, 29]. The cash reserves were used to cover operating expenses by deferring repayments of bank loans.

What are the factors that create a statistically functional relationship with the negative exposure to banks during the pandemic period, for Albanian businesses?

The processing of data with the inferential statistical methods, using SPSS software, reveals that from all the factors included in the study to assess exposure to crediting, manifested as repayment delay, only two factors are shown to be significantly included in the linear regression model: exercise of activity and use of cash reserves:

"Delay of Loan Payment" $=(2.894)-(0.438) \times$ ("Activity during Quarantine") $+(0.335) \times$ ("Usage of Cash Reserves") $+\varepsilon$

Table 1. Correlations

\begin{tabular}{|c|c|c|c|c|c|c|c|c|}
\hline \multicolumn{9}{|c|}{ Correlations } \\
\hline & & $\begin{array}{l}\text { Business } \\
\text { size }\end{array}$ & $\begin{array}{l}\text { Business } \\
\text { Age }\end{array}$ & $\begin{array}{l}\text { Covid } \\
\text { Impact }\end{array}$ & $\begin{array}{c}\text { Activity } \\
\text { during } \\
\text { Quarantine }\end{array}$ & $\begin{array}{c}\text { Failure } \\
\text { Perception }\end{array}$ & $\begin{array}{c}\text { Accuracy } \\
\text { of Receipts }\end{array}$ & $\begin{array}{c}\text { Usage of } \\
\text { cash } \\
\text { reserves }\end{array}$ \\
\hline \multirow{2}{*}{ Business Size } & $\mathrm{PC}$ & 1 & & & & & & \\
\hline & Sig. (2-t) & & & & & & & \\
\hline \multirow{2}{*}{ Business Age } & $\mathrm{PC}$ & -.136 & 1 & & & & & \\
\hline & Sig. (2-t) & .204 & & & & & & \\
\hline \multirow{2}{*}{ Covid-19 Impact } & $\mathrm{PC}$ & $-.273^{* *}$ & -.073 & 1 & & & & \\
\hline & Sig. (2-t) & .010 & .494 & & & & & \\
\hline \multirow{2}{*}{$\begin{array}{c}\text { Activity during } \\
\text { quarantine }\end{array}$} & $\mathrm{PC}$ & .089 & .031 & $-.419^{* *}$ & 1 & & & \\
\hline & Sig. (2-t) & .411 & .772 & .000 & & & & \\
\hline \multirow{2}{*}{$\begin{array}{c}\text { Failure } \\
\text { Perception }\end{array}$} & $\mathrm{PC}$ & $-.233^{*}$ & $.372^{* *}$ & $.392^{* *}$ & $-.338^{* *}$ & 1 & & \\
\hline & Sig. (2-t) & .028 & .000 & .000 & .001 & & & \\
\hline \multirow{2}{*}{$\begin{array}{l}\text { Accuracy of } \\
\text { Receipts }\end{array}$} & $\mathrm{PC}$ & -.129 & -.122 & .079 & .170 & -.083 & 1 & \\
\hline & Sig. (2-t) & .229 & .254 & .461 & .116 & .440 & & \\
\hline \multirow{2}{*}{$\begin{array}{l}\text { Usage of cash } \\
\text { reserves }\end{array}$} & $\mathrm{PC}$ & .046 & $.224^{*}$ & .172 & .057 & $.360^{* *}$ & -.019 & 1 \\
\hline & Sig. (2-t) & .667 & .035 & .107 & .603 & .001 & .861 & \\
\hline \multicolumn{9}{|c|}{ *. Correlation is significant at the 0.01 level (2-t). } \\
\hline & & & taton & icant a & 05 level $(2-t)$ & & & \\
\hline
\end{tabular}

Source: Analysis of the authors

Table 2. Linear regression coefficients

\begin{tabular}{|c|c|c|c|c|c|c|c|}
\hline \multicolumn{8}{|c|}{ Coefficients $\mathrm{s}^{\mathrm{a}}$} \\
\hline \multirow{2}{*}{ Model } & \multicolumn{2}{|c|}{ Unstandardized Coefficients } & \multirow{2}{*}{$\begin{array}{c}\begin{array}{r}\text { Standardized } \\
\text { Coefficients }\end{array} \\
\text { Beta }\end{array}$} & \multirow{2}{*}{$\mathrm{t}$} & \multirow{2}{*}{ Sig. } & \multicolumn{2}{|c|}{$\begin{array}{c}95.0 \% \text { Confidence Interval } \\
\text { for B }\end{array}$} \\
\hline & B & Std. Error & & & & L. Bound & U. Bound \\
\hline (Constant) & 2.894 & .486 & & 5.949 & .000 & 1.922 & 3.866 \\
\hline Activity during Quarantine & -.438 & .131 & -.371 & -3.335 & .001 & -.700 & -.176 \\
\hline Usage of Cash Reserves & .335 & .116 & .321 & 2.887 & .005 & .103 & .566 \\
\hline
\end{tabular}

Source: Analysis of the authors 
The coefficients of the above equation (extracted from Table 2) indicate that if a business is operative, it reduces $(\mathrm{UC}=-.438)$ the delay in loan repayments by $44 \%$, whereas using the firm's cash reserves increases delay by nearly $34 \%(\mathrm{UC}=.335)$. The lack of sufficient liquidity increases the chances of failure to repay loans. For this reason, many governments intervened by introducing sovereign guarantees or reduced interest rates [3].

Crediting and fear of using bank loan as an alternative source of financing

COVID-19 pandemic had a negative impact on communities, businesses and organizations globally, inadvertently affecting the financial markets and the global economy. Uncoordinated governmental responses and lockdowns led to a disruption in the supply and demand chain. [30]. During the pandemic, firms moved heavily towards the use of bank loans, requiring the opening of new credit lines or extending the existing ones $[31,15]$. If management of existing (pre- Covid-19) credits is important to avoid business failure and the domino effects in all sectors including the financial sector, the current financing of existing and new businesses is perhaps more vital for the recovery of economy.

The results of correlation between factors influencing the stimulation and creation of an optimistic climate for lending of Albanian businesses indicate that these factors are statistically related to one-another by "pulling" one-another in the same direction. Some questions of the questionnaire aimed at collecting data about the obstacles created by factors presented in Table 3 to measure the level of "pessimism" among businesses to ask banks for financing opportunities.

In general, an increase in perception of obstacles created by the terms of contract is accompanied by an increase in "dissatisfaction" with the business climate, in general, and government policies in terms of businesses financing through bank lending. This is also accompanied by an increased level of perception that businesses are experiencing a difficult period.

Considering the strong positive correlation $(\mathrm{PCC}=0.554)$ between the terms of contract and interest rate for business loans, the positive correlation between interest rate and business climate $(\mathrm{PCC}=0.416)$, government policies $(\mathrm{PCC}=0.386)$ and difficulties businesses are experiencing in this difficult period, we can reach in a significant conclusion that the pandemic created a pessimistic climate in Albanian businesses that made them pessimistic about asking bank lending to finance their growth. The results of our study reveal that the difficulties businesses are experiencing during this pandemic period and the government policies introduced to help business overcome these difficulties have affected positively in fostering an uncertainty climate for Albanian businesses. These two factors are creating an increasing pessimistic climate for Albanian business to ask banks for lending as a financing opportunity for their business.

Table 3. Correlations

\begin{tabular}{|c|c|c|c|c|c|c|c|}
\hline \multicolumn{8}{|c|}{ Correlations (between the borrowing inhibitory factors) } \\
\hline & & $\begin{array}{c}\text { Contract } \\
\text { Terms } \\
\end{array}$ & Interest Rate & $\begin{array}{c}\text { Business } \\
\text { Difficulties } \\
\end{array}$ & $\begin{array}{c}\text { Business } \\
\text { Environment }\end{array}$ & $\begin{array}{c}\text { Government } \\
\text { Policies }\end{array}$ & Uncertainty \\
\hline \multirow{2}{*}{ Contract Terms } & $\mathrm{PC}$ & 1 & & & & & \\
\hline & Sig. (2-t) & & & & & & \\
\hline \multirow{2}{*}{ Interest Rate } & $\mathrm{PC}$ & $.554^{* *}$ & 1 & & & & \\
\hline & Sig. (2-t) & .000 & & & & & \\
\hline \multirow{2}{*}{ Business Difficulties } & $\mathrm{PC}$ & $.311^{* *}$ & $.417^{* *}$ & 1 & & & \\
\hline & Sig. $(2-t)$ & .004 & .000 & & & & \\
\hline \multirow{2}{*}{$\begin{array}{c}\text { Business } \\
\text { Environment }\end{array}$} & $\mathrm{PC}$ & $.391^{* *}$ & $.416^{* *}$ & $.490^{* *}$ & 1 & & \\
\hline & Sig. (2-t) & .000 & .000 & .000 & & & \\
\hline \multirow{2}{*}{$\begin{array}{l}\text { Government } \\
\text { Policies }\end{array}$} & $\mathrm{PC}$ & $.485^{* *}$ & $.386^{* *}$ & $.382^{* *}$ & $.501^{* *}$ & 1 & \\
\hline & Sig. $(2-t)$ & .000 & .000 & .000 & .000 & & \\
\hline \multirow{2}{*}{ Uncertainty } & $\mathrm{PC}$ & .208 & .099 & $.268^{*}$ & .177 & $.366^{* *}$ & 1 \\
\hline & Sig. (2-t) & .058 & .369 & .012 & .103 & .001 & \\
\hline \multicolumn{8}{|c|}{$* *$. Correlation is significant at the 0.01 level $(2-t)}$. \\
\hline \multicolumn{8}{|c|}{ *. Correlation is significant at the 0.05 level (2-t). } \\
\hline
\end{tabular}

Source: Analysis of the authors 
Table 4. Linear regression coefficients

\begin{tabular}{|c|c|c|c|c|c|c|c|}
\hline \multicolumn{8}{|c|}{ Coefficients $^{\text {a }}$} \\
\hline \multirow{2}{*}{ Model } & \multicolumn{2}{|c|}{$\begin{array}{c}\text { Unstandardized } \\
\text { Coefficients }\end{array}$} & \multirow{2}{*}{$\begin{array}{c}\begin{array}{c}\text { Standardized } \\
\text { Coefficients }\end{array} \\
\text { Beta }\end{array}$} & \multirow[t]{2}{*}{$\mathrm{t}$} & \multirow{2}{*}{ Sig. } & \multicolumn{2}{|c|}{$\begin{array}{l}95.0 \% \text { Confidence Interval } \\
\text { for B } \\
\end{array}$} \\
\hline & B & Std. Error & & & & L. Bound & U. Bound \\
\hline (Constant) & 2.679 & .660 & & 4.061 & .000 & 1.366 & 3.991 \\
\hline Government Policies & -.585 & .131 & -.511 & -4.462 & .000 & -.845 & -.324 \\
\hline Interest Rate & .436 & .112 & .411 & 3.890 & .000 & .213 & .659 \\
\hline Uncertainty & .295 & .145 & .216 & 2.034 & .045 & .006 & .584 \\
\hline
\end{tabular}

Source: Analysis of the authors

The outbreak of COVID-19 around the world increased uncertainty along the entire value chain [32], an uncertainty that stems from various events that can have positive or negative consequences for business [33]. The analysis of correlations between the factors considered as an obstacle for business to ask bank lending shows a significant government presence in business perception, represented by two factors: interest rates and contract terms. The regression model below (Table 4) shows the impact of government policies.

The significant econometric model expressing the linear regression between the dependent variable and the factors of Table 3, as independent variables, has the following formula:

$$
\begin{gathered}
\text { "Credit" }=(2.679)+(-0.585) \times(\text { “G. Policies") })+(0.436) \times \\
\text { ("Interest Rate") }+(0.295) \times(\text { ("Uncertainty") }+\varepsilon
\end{gathered}
$$

Based on this econometric equation, we can conclude that decreasing with a unit the perception that government policies are an obstacle to businesses would increase with $58.5 \%$ the perception that bank lending is a good financing opportunity for their business.

The increase in uncertainty for the future is related to the firm's liquidity. When asked about the reasons for taking credits, $50 \%$ of the respondents said that they had liquidity issues. A low level of liquidity can affect business continuity [34]. [35] argue that some firms seek access to credit on a contingent basis (referred to a future conditioned by events that are not under the control of firms), reflecting uncertainty over both the duration of containment policies and the timeframe for business recovery. [36], in their mathematical model, predicted that a second lockdown would have major impacts on liquidity needs.

"Why the increase in perception of interest rate and uncertainty as impeding factors in crediting have a positive sign before the coefficient?

Under the conditions of uncertainty and a financial system represented mostly by the banking sector, credit lending outside this sector is difficult and much costly. The same was said by [28] who argue that the first businesses to use credit lines in the early stages of the crisis were lower-rated and unrated firms. The reason behind this was the difficulty in finding other forms of lending and financing. Financially constrained firms face higher borrowing costs compared to non-constrained ones [31].

\section{Conclusions}

As is widely known, during Covid-19 pandemic, businesses faced several challenges in terms of liquidity, high cost of financing loans, decline of sales, slowdown in payments or repayments, etc. All of these had a role in creating a pessimistic perception that entrepreneurs are perceiving themselves. Referring to the literature review and the results of our study, big firms have a lower susceptibility towards the pandemic impacts on their business, as well as a lower sensitivity towards fear of failure due to pandemic collapse. On the contrary, small firms feel more Covid-2019 impacts on weakening their business. They also have an increased fear of failure risk.

In pandemic conditions, banks are buffers of liquidity crisis of the private sector and the economy in general. Bank lending, as one of the key measures and business supports in the early onset of the pandemic, enables businesses to overcome Covid shock smoothly and with less impacts, thus minimizing the perceived pessimistic view and empower them to recover faster. Referring to other studies and based on the results of our study, we reach in the conclusion that strong firms with high liquidity available will have the opportunity to create an advantage compared to other firms, and at the same time save their business from crisis and avoid business failure.

Businesses should be cautious not only about the crisis management during Covid-2019 shock period, but also to have a plan for their business performance in the future. Many firms may find themselves considerably increasing their debt/financing, which in turn may be difficult to repay for as long as economic contraction is continuing. Furthermore, contracts with the suppliers, creditors or the government need to be analyzed and, for this job, legal, tax and financial expertise is required. Therefore, a closer cooperation between private sector firms willing to seize the opportunities created, banks and financial 
consultants/experts is necessary. Considering this situation and the business needs, for the economy to resume its pre-pandemic performance, a clarification of the situation is necessary now more than ever.

Facilitating the application procedures for granting the necessary financing, as well as alleviating the contracts terms were among the practices followed by the second-tier banks.

In the perception of firms, the lengthy and bureaucratic loan application procedures, as well as the burdensome contract terms are, in general, considered key obstacles that cause an increasing dissatisfaction and not helpful for the business climate. Here, the government could intervene with policies to alleviate and facilitate businesses financing through bank lending.

\section{Recommendations for Business Recovery}

"We will win the "war" against COVID-19, but in many ways, the world will never be the same again after COVID-19.'”[37]

Adapting and fitting Albanian businesses for the new Covid-19 reality is not an option but vital for the business survival and gradual recovery. After a comprehensive literature review and empirical research, some recommendations could be given to domestic firms and their crediting behavior. Business crediting is not something done and ended instantly at a given moment. On the contrary, it starts with the need for financing and ends with loan repayment. If no caution is shown, the liquidity issues could quickly turn into insolvency problems [13]. Therefore, more attention should be paid to the following issues:

Need for Financial Analysis: Covid-19 came out of a sudden for all firms, but not all were able to cope with the situation. One of the main reasons behind these circumstances was the lack of expertise in managing cash flows. Therefore, introducing a future-oriented spirit through a more comprehensive treatment of firm is suggested.

Considering Bank Sector as a Partner: Albanian firms widely lean on bank sector for funds. If in other countries, the banking sector was considered important to mitigate the crisis triggered by Covid-19, it is vital for the survival and recovery of Albanian firms. However, the firm and bank cooperation should not be viewed only unilaterally as a claim to the latter for business financing, but as a transparent cooperation between two parties. This would create an opportunity to arrange loan contracts on favorable terms for both parties. According to [38], loan provides benefits for both the bank and borrower. The benefits for banks are the profits on interest paid by the borrower. As for the borrower (debtor), lending is a mean providing for more funds to expand and upgrade the business. Another recommendation is that more favorable contract terms be arranged for both parties.

Financial Education: According to some studies, financial support is more effective when provided together with non-financial support, which includes mentoring, assistance, counseling or general financial education [39]. Businesses should also shift their attention towards universities in studying the crisis triggered by Covid-19 and providing suggestions for the future. Transactional data held by private companies have great potential for measuring economic activity [40].

\section{REFERENCES}

[1] Douglas W. A., Janos N. B., Julia W., Ross P. B., Andrew M. D., Dirk A. Z., "Digital Finance \& the COVID-19 Crisis", "University of Hong Kong Faculty of Law Research Paper" no. 2020/017, pp. 1-23, 2020, http://dx.doi.org/10.2139/ssrn.3558889

[2] AIC (Albanian Investment Council), (2020) Assessment of the Impact of the COVID-19 Pandemic on Business in Albania", https://bit.ly/3azxBd5

[3] Pierre-Olivier G., Șebnem K-Ö., Veronika P., NickS., "COVID-19 and SME Failures", "Sander NBER Working Paper", no. 27877, pp. 1-60, 2021,http://www.nber.org/pap ers/w27877

[4] Hamid Y., "Emerging social and business trends associated with the Covid-19 pandemic", critical perspectives on international business, pp. 1742-2043,2021, https://doi.org/10.1108/cpoib-05-2020-0066

[5] Benedikt Z.-R., Florian K.,"COVID-19: Guaranteed Loans and Zombie Firms", pp. 1-52, SSRN: https://ssrn.com/abstract=3619744 http://dx.doi.org/10.2139/ssrn.3619744

[6] Abel B., David M. G., Anik I., Suraiya B., "A Literature Review of the Economics of Covid-19",'IZA Discussion Paper", no. 13411, pp. 1-61, 2020, SSRN: https://ssrn.com/abstract $=3636640$

[7] Joseph A.-A., Zaheer K., Geoffrey W., "COVID-19 and business failures: The paradoxes of experience, scale, and scope for theory and practice", "European Management Journal", vol. 39, no. 2, pp. 179-184, 2021, https://doi.org/10.1016/j.emj.2020.09.002

[8] Surabhi V., Anders G., "Investigating the emerging COVID-19 research trends in the field of business and management: A bibliometric analysis approach", "J. Bus. Res.”, vol. 118, pp. 253-261, 2020, https://doi.org/10.1016/j.jbusres.2020.06.057

[9] C.W. Potter, "A history of influenza", "Journal of Applied Microbiology”, vol. 91, pp. 572-579, 2001, https://doi.org/10.1046/j.1365-2672.2001.01492.x.

[10] Claudio B., "The Covid-19 economic crisis: dangerously unique", "Bus Econ", vol. 55, pp. 181-190, 2020, https://doi.org/10.1057/s11369-020-00184-2. 
[11] OECD, 2020, Evolution and Trends in SME Finance Policies since the Global Financial Crisis https://doi.org/10.1787/061fe03d-en

[12] Adrian R.M, "Trade in the Time of Corona: Broken Chains and Mended Barriers", Discussion Paper no.05, 2020. https://econ.upd.edu.ph/dp/index.php/dp/article/download/ $1528 / 1011$

[13] Tatiana D., Federico H., Mauricio L., Sergio L.S., "Financing Firms in Hibernation during the COVID-19 Pandemic", "Journal of Financial Stability",vol. 53, pp 1-7, 2021, https://doi.org/10.1016/j.jfs.2020.100837

[14] Janmenjoy N., Manohar M., Bighnaraj N., Hanumanthu S., Korhan C., Vimal S., "An impact study of COVID-19 on six different industries: Automobile, energy and power, agriculture, education, travel and tourism and consumer electronics". Expert Systems, Wiley, pp. 1-32. 2020, https://doi.org/10.1111/exsy.12677

[15] Rüdiger F., Kevin R., René S., "How Valuable is Financial Flexibility When Revenue Stops? Evidence from the Covid-19 Crisis", NBER Working Paper, no. w27106, 2020,http://dx.doi.org/10.2139/ssrn.3586540

[16] Fabrizio C., Marco F., "Inter-Enterprise Credit and Adjustment During Financial Crises: The Role of Firm Size", "Journal of Money, Credit and Banking" vol. 51, no. 6, pp. 1547-1580, 2016,https://doi.org/10.1111/jmcb.12557

[17] Asli. D.-K., Alvaro M., Claudia O.R., "Banking Sector Performance During the COVID-19 Crisis", World Bank Policy Research Working Paper 9363,2020, SSRN: https://ssrn.com/abstract $=3689789$ http://dx.doi.org/10.2139/ssrn.3689789

[18] Dylan B.E., Zoe C., Edward L.G., Michael L., Christopher S., "Business Re-Opening During the COVID-19 Pandemic", "Harvard Business School Entrepreneurial Management Working Paper" no. 20-132, Harvard Business School NOM Unit Working Paper no. 20-132, Available at SSRN: https://ssrn.com/abstract=3634162 or http://dx.doi.org/10.2139/ssrn.3634162

[19] Tarek A.H., Stephan H., Laurence van L. Markus S., Ahmed T., "Firm-Level Exposure to Epidemic Diseases: COVID-19, SARS, and H1N1"2021, SSRN: https://ssrn.com/abstract $=3566530$ http://dx.doi.org/10.2139/ssrn.3566530

[20] Lindsay C., Clear B., "How Covid-19 is escalating problem debt”, 2020, https://www.ft.com/content/4062105a-afaf-4b 28-bde6-ba71d5767ec0

[21] Craig S. F., Sheila W., "Causes of Competitive Analysis Failure: Understanding and Responding to Problems at the Individual Level", "Third European Competitive Intelligence Symposium (ECIS)", Stockholm, Sweden, Proceedings, pp 36-50, 2009, http://hdl.handle.net/2086/45 18

[22] Francisco J. B., Roberto N. F.-J., Hugo H., Andrés A.; Yongseok S., "The Economic Ripple Effects of COVID-19",'NBER Working Paper" no. 28704, 2020, DOI $10.3386 / \mathrm{w} 28704$

[23] Antonina L., Alexandra K., "Measures of Financial and Non-Financial Support to Small and Medium-sized Enterprises (SMEs) in the Wake of COVID-19", "Monitoring of Russia's Economic Outlook. Trends and
Challenges of Socio-economic Development. Moscow". IEP. no. 9, pp. 7-10, 2020, SSRN: https://ssrn.com/abstract $=3629597$ http://dx.doi.org/10.2139/ssrn.3629597

[24] Elena C., Tommaso O., Marco P., Loriana P., Marti G. S., "The COVID-19 shock and equity shortfall: Firm-level evidence from Italy", "SAFE Working Paper", no. 285, Leibniz Institute for Financial Research SAFE, Frankfurt a. M., 2020,http://nbn-resolving.de/urn:nbn:de:hebis:30:3-55 2455

[25] André D., Kweilin E., Deepa M., Jake S., "Which small businesses are most vulnerable to COVID-19- and when", 2020 // McKinsey \& Company, https://familyenterprisefou ndation.org/media/2526/which-small-businesses-are-mostvulnerable-to-covid-19-and-when-vf.pdf

[26] Jonathan I. Dingel and Brent Neiman, "How Many Jobs Can be Done at Home?", "NBER Working Paper" no. 26948, 2020, https://doi.org/10.1016/j.jpubeco.2020.10423 5

[27] Martin C., Beata G., Jan D., Jaroslav B., "The impact of the COVID-19 crisis on the perception of business risk in the SME segment", "Journal of International Studies", vol. 13, no. 3 , pp. $248-263$, 2020, doi:10.14254/2071-8330.2020/13 $-3 / 16$

[28] Acharya, Viral V. and Steffen, Sascha, The Risk of Being a Fallen Angel and the Corporate Dash for Cash in the Midst of COVID, Covid Economics, no. 27, pp. 44-61, 2020, SSRN: $\quad$ https://ssrn.com/abstract $=3654248 \quad$ or http://dx.doi.org/10.2139/ssrn.3654248

[29] Dimitriy V. T., Konstantin I. K., "Some questions about the impact of the COVID-19 pandemic on the development of business entities", International Scientific Journal Theoretical \& Applied Science", vol. 91, no. 11, pp. 1-4, 2020, https://dx.doi.org/10.15863/TAS.2020.11.91.1

[30] Maria N., Zaid A., Catrin S., Ahmed K., Ahmed A.-J., Christos I., Maliha A., Riaz A., "The Socio-Economic Implications of the Coronavirus and COVID-19 Pandemic: A Review", "International Journal of Surgery", vol. 78, pp. 185-193, 2020,https://doi.org/10.1016/j.ijsu.2020.04.018.

[31] Iftekhar H., Panagiotis N. P., Zenu S., "Global Syndicated Lending during the COVID-19 Pandemic", "Journal of Banking \& Finance”, 2021, https://doi.org/10.1016/j.jbank fin.2021.106121

[32] Naveen D., Anders G., "Effects of COVID-19 on business and research". "Journal of Business Research", vol. 117, pp. 284-289, 2020, https://doi.org/10.1016/j.jbusres.2020.06.0 08

[33] Priscila F. De A. L., Maria C., Chiara V., "Risk management in SMEs: A systematic literature review and future directions, "European Management Journal", vol. 38, no.1, pp. 78-94, 2020, https://doi.org/10.1016/j.emj.2019.0 6.005

[34] Sri M. R., "The Role of Moderation in Fund Structure on the Impact of Liquidity, Business Risk and Resource Use Activities on Company Value as a Variable that Influences Company Values", "Journal of Critical Reviews", vol. 7, no. 13, pp. 863-872, 2020, doi:10.31838/jcr.07.13.147

[35] Niall McG., John McQ., Samantha M., "SME liquidity 
needs during the COVID-19 shock", "Financial Stability Notes, Central Bank of Ireland", no. 2/FS/20, pp. 1-12, 2020,https://EconPapers.repec.org/RePEc:cbi:fsnote:2/fs/2 0

[36] Fabiano S., Romano G., "A simple method to estimate firms liquidity needs during the COVID-19 crisis with an application to Italy," Covid Economics, vol. 35, pp. 51-69. 2020, http://hdl.handle.net/11385/198776

[37] Desheng D. W., David L. O., "The Effect of COVID-19 on the Banking Sector", "Pandemic Risk Management in Operations and Finance: Computational Risk Management", Springer, Cham. pp 89-99, 2020, https://doi.org/10.1007/9 78-3-030-52197-4_8

[38] Jerimieus S S., Iskandar M., Amlys S. S., "The Effect of BI
Rate, Exchange Rate, Inflation and Third-Party Fund (DPK) on Credit Distribution and Its Impact on Non-Performing Loan (NPL) on XYZ Commercial Segment Bank," Universal Journal of Accounting and Finance, Vol. 8, No. 3, pp. 55 - 64, 2020. DOI: 10.13189/ujaf.2020.080301.

[39] OECD, "PISA 2015 results (Volume IV): students' financial literacy", Paris: PISA, OECD Publishing, 2017, https://doi.org/10.1787/9789264270282-en.

[40] Raj C., John N. F., Nathaniel H., Michael S., "The Economic Impacts of COVID19: Evidence from a New Public Database Built from Private Sector Data,", "Opportunity Insights Working Paper", 2020, https://opportunityinsights.org/wp-content/uploads/2020/0 5/tracker_paper.pdf 